\title{
Collaborative Strategy for Rice Supply Chain: A Case Study on Demak and Sukoharjo Regency, Central Java, Indonesia
}

\author{
Adi Djoko Guritno, Novita Erma Kristanti, Megita Ryanjani Tanuputri* \\ Department of Agro-Industrial Technology, Faculty of Agricultural Technology, \\ Universitas Gadjah Mada, Jl. Flora No. 1, Bulaksumur, Yogyakarta 55281, Indonesia \\ *Corresponding author: Megita Ryanjani Tanuputri, Email: megita.ryanjani@mail.ugm.ac.id
}

Submission: August 21, 2019; Revision: March 10, 2020; April 10, 2020; Acceptance: April 22, 2020

\begin{abstract}
The problems associated with rice production in Indonesia appear very complicated, due to poor management of the sufficient national rice stock and various unfavorable public policies. Recently, government's directives on rice importation instigated polemics from several interests, as a result of inappropriate decisions on general rice production, with possible yearly increment. Therefore, there is need to embrace strategy development to balance demand and supply. The purpose of this study was to analyze the rice supply chain in Demak and Sukoharjo, Central Java Province, in an effort to provide effective and collaborative distribution policies at individual levels. In addition, in-depth interviews were conducted for 98 respondents in a bid to acquire relevant and current information for the conceptual framework development. Furthermore, sampling methodologies, termed purposive and snowballing, were applied, followed by the preparation of interview guidelines. The results showed the farmers obtained the lowest revenue margin among other tiers, while several technical challenges were also identified. Consequently, the activities of middlemen with excessive dominant roles in market price determination, were overemphasized, leading to an inefficient supply chain. Meanwhile, government's position through the Indonesia Logistics Bureau (BULOG) is assumed to be vulnerable in the control of direct supply from farmers or collectors. Based on this study, intense comprehension of rice supply chain was achieved, with further provision of collaborative strategies towards promoting the balance of demand and supply.
\end{abstract}

Keywords: Collaborative strategy; rice; supply chain

\section{INTRODUCTION}

Rice remains a significant staple commodity consumed by a majority of Indonesia's 255.46 million population, with a rate extending to $117 \mathrm{~kg} / \mathrm{capita}$ per year, based on 2017 data from the Ministry of Agriculture. Meanwhile, 2016 statistics showed a positive inclination in national production. Therefore, there is a high demand on government to prioritize sustainable supply in order to encourage food sovereignty. During the period between 2012-2016, the growth rate of this crop increased annually by $3.8 \%$, and Java Island was known to contribute $51.9 \%$ of the general scale. The national rice production on 2018 was estimated at 56.54 million tons dry unhusked paddy (known as GKG), where $16.8 \%$ originated from Central Java (Statistics Indonesia, 2018). However, the country currently imports the product, with a steady increase observed in the last 3 years. In 2015, the importation volume extended to 861.63 thousand tons (Ministry of Agriculture, 2016). These provisions obviously conflict with the yearly increment in terms of production. Recently, government's policies on rice importation resulted in polemics, due to inappropriate decisions on peak harvest seasons in several provinces. The directives were expected to instigate a price reduction from local farmers and also attempt to eliminate unfair competitions (Sathapatyanon et al., 2018). 
In reality, the balance between demand and supply is essential, due to the influence on market price, where the government attempts to regulate to an acceptable level. Figure 1 reveals an excess of approximately 2.85 million tons in the national rice production in 2018, and the surplus was anticipated during 2016 - 2019 (Statistics Indonesia, 2018; Ministry of Agriculture, 2016). However, government's decision to import rice worth 2 million tons in 2018 did not match this projection. Moreover, the country has implemented several programs, including the provision of planting support and the use of appropriate technology, towards promoting productivity and securing rice supply from farmers. Meanwhile, the problem of rice is not only in terms of output, but also in the complex distribution process, as a result of numerous stakeholder involvement and inefficient logistics activities. Therefore, a collaborative strategy along the supply chain is necessary in an effort to enhance national rice conditions. This study was aimed at analyzing the rice supply chain in Central Java, particularly in Demak and Sukoharjo, in order to generate collaborative strategies for the promotion of effective distribution.

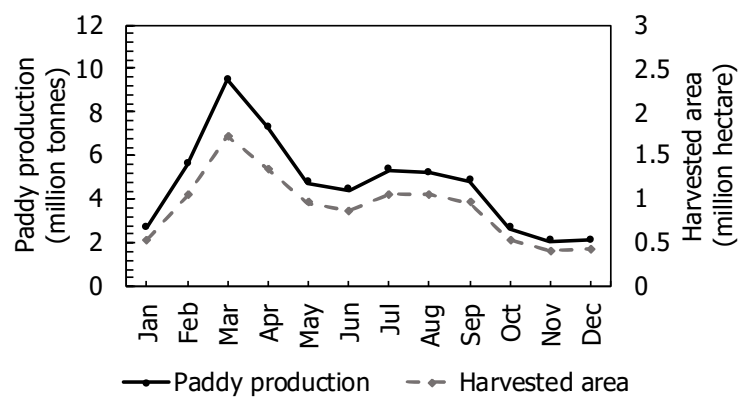

(a) snowballing technique determined the respondents. Also, in-depth interview was conducted to acquire and analyze sensitive information of the current situation from participants, including farmers, collectors, traders, as well as the Indonesia Logistics Bureau (BULOG), otherwise referred as government representative. In addition, supply chain problems were identified, as well as the subsequent development of collaborative strategies, using the conceptual framework.

\section{RESULTS AND DISCUSSION}

\section{The Supply Chain of Rice in Central Java Province}

This study evaluated the general rice supply chain in Demak and Sukoharjo, Central Java, comprising six stakeholders, termed farmer, middleman (or harvester), rice miller, trader, BULOG and retailer, as shown in Figure 2. The arrow indicates the flow of rice from farmer to customer and the underlying possibility, while the dotted line reflects the combined roles of rice miller and trader. Each stakeholder obtained separated responsibility, with the tendency for an extension. In addition, in-depth

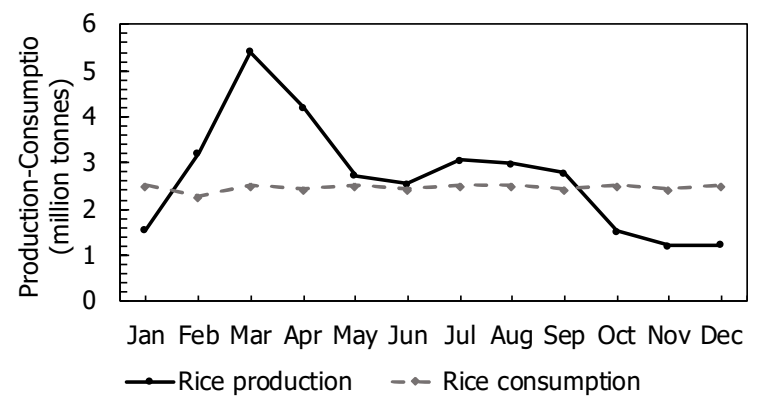

(b)

Notes: October - December data was estimated number

Figure 1. The trend of harvested area and paddy production (a), and rice production and rice consumption (b) of Indonesia on 2018. Source: Statistics Indonesia (2018)

\section{METHODS}

This study was conducted in two regencies in Central Java province, termed Demak and Sukoharjo. Demak was chosen on the basis of being the $3^{\text {rd }}$ highest rice producer in Central Java, with an estimated 7.1\% of the total output in 2018 (Statistics Indonesia, 2018). Meanwhile, Sukoharjo produced approximately half this value, but occurred as the largest in terms of productivity (Statistics Indonesia, 2020), with possible government intervention, including the provision of intensive support in the form of agricultural equipment and machinery. Furthermore, purposive sampling was employed in the site selection process, while interview was performed on 98 respondents in order to acquire detailed information on current rice supplydemand and distribution conditions.

According to Guritno (2016), farmers as initial suppliers, typically show a high level of risk, in terms of natural disaster occurrence and crop failure. Subsequently, the possibilities enlarges as the market's response to prices becomes uncertain, and in turn, influences the expected income. This study observed the Demak farmers controlled an average paddy field area of $11,723 \mathrm{~m}^{2}$, as most planters, in addition tend to manage and/or rent from others in order to enhance production. Meanwhile, in Sukoharjo, only $8,000 \mathrm{~m}^{2}$ was recorded, and these portions were self-managed. 


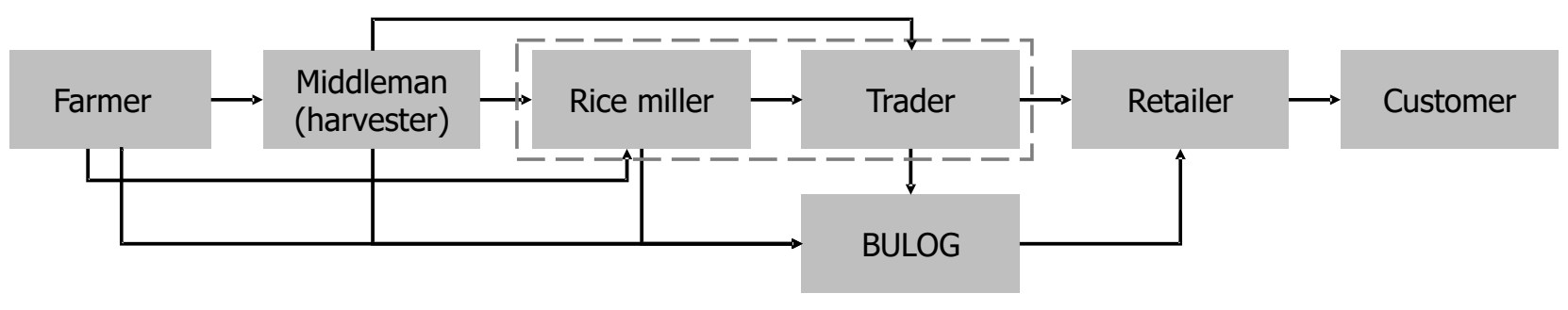

Figure 2. The supply chain of rice in Central Java Province

Previous study by Fukui et al. (2002), discovered the production efficiency under tenancy land is not lower compared to owned land. Furthermore, the reaping process in Demak commonly applies combine harvester, due to wider available space, while bidding and bargaining normally commence 14 days prior to harvest. Under the condition of insufficient institutional loan, certain smallholders tend to borrow money from middlemen with a mutual agreement to purchase the harvested tea leaves as a means of repayment, as also observed in similar case by Rahman and Takeda (2007).

Middleman refers to is a third party service provider in harvesting the paddy without any added value, while a fraction act as the broker between farmer and buyer. Conversely, rice millers and traders possibly partake in the bargaining process and mostly during post-harvest activities, including drying, milling, and packing, as the product are generally sold to these individuals. Several traders also act as the rice miller, particularly for large scale, with ownership to the rice milling unit (RMU). This type of operation is more prevalent in Demak, where traders mill, pack, and distribute the rice. Large buyers also owned milling unit, with the capacity to handle a huge volume of the farm produce.

The role of Indonesia Logistics Bureau (BULOG) as government representative in rice supply chain, is clearly inseparable. In addition, the agency is described as a state-owned establishment in food logistics, and is saddled with the responsibility of regulating basic price of the commodity, ensuring price stability, particularly the cost of goods, distributing the product to the poor, otherwise called "Raskin", and properly managing the food stock, using import and export monopolies. Under this authority, the government is required to devise innovative solutions in order to strengthen food security, by actualizing food sovereignty, resilience, and safety. Furthermore, BULOG focuses on a balance between supply units or production and demand (Guritno et al., 2018). Based on media report, the agency usually regulates a rice stock of 2 million tons with the best reserve of 3 million tons, and this study intends to produce $8,147 \mathrm{~kg}$ and $6,943 \mathrm{~kg}$, in a single hectare of land in Demak and Sukoharjo, respectively. Moreover, farmers either choose to sell to middleman, rice miller, trader or BULOG, depending on the highest price bid and engagement. Subsequently, retailers are divided into large and small, and are easily located in the traditional market and close surroundings. However, the difference between both groups are the buying and selling capacity. Large retailers typically trade in higher quantity, using big packed sizes, including $50 \mathrm{~kg}, 10 \mathrm{~kg}$ or $5 \mathrm{~kg}$ and also supply the packed rice to the small retailers, where the product is then unpacked and sold per $\mathrm{kg}$ to customers.

\section{The Current Issues}

The supply chain of rice appears complex, due to the number of stakeholder involvement and results in the length of flow. This study revealed the farmer acquires the lowest revenue among rice miller/trader, while the retailer generated approximately IDR 300 $600 / \mathrm{kg}$ of paddy rice. Previous study by Adam et al., (2017) also reported the trading and transportation margin (TTM) of rice farmer in South Sumatera, Indonesia was higher than trader, despite the extensive nominal transaction value by trader compared to farmer. Meanwhile, Antriyandarti (2015) observed the reduction of land rent, fertilizer price, and tractor cost was more effective in cutting down production cost. Figure 3 shows the highest revenue occurrence in the RMU or trader tier, where the average purchasing price (PP) and selling price (SP) attained IDR 4,933/kg and IDR 9,386/ $\mathrm{kg}$, respectively, although, revenue for the retailer was estimated at IDR $800 / \mathrm{kg}$. Furthermore, the maximum value added was evident in RMU or trader, due to observing most of the post-harvest activities, while the greatest risk occurred in the farmer stage, with possible event of crop failure and environmental uncertainty. According to Chung et al. (2016), large private rice milling units generated higher profit margins, due to economies of scale or lower average of total costs, while lesser RMU appeared the most vulnerable, particularly as poor harvest resulted in paddy production shortage.

Figure 4 represents the conceptual framework for the implementation and management of rice supply chain, based on observation and in-depth field 
interview. According to Lambert et al. (1998), the framework element include the structure (refers to key supply chain members to link the process), business process (required methods to connect each of these key stakeholders), and management components (level of integration and management to apply for each process termed supply, demand, price, margin distribution, and national rice stock. Previous study by Kumar et al. (2006), revealed the control mechanism was known to trigger an alarm, indicating certain adjustments are required to enhance supply chain activities and business performance.

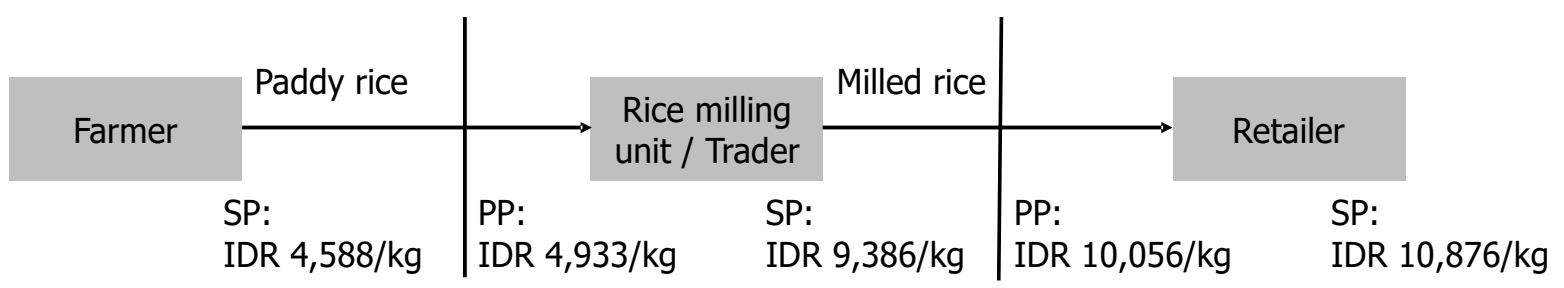

Figure 3. The diagram of increasing price along the supply chain of rice in Central Java Province

link). However, the farmer often acting as the supplier, plays a significant role in ensuring rice stock availability by continuous planting. Also, the competitiveness and bargaining capacity is primarily dependent on four factors. First, the price and availability of input materials e.g., fertilizer, labor cost, and seed, contribute to total cost. Second refers to environmental uncertainty, as discussed by Correa (1994), where over time, an organization or entity tend to encounter certain planned and unplanned events, resulting to the need to develop essential contingency strategies.

Thirdly, in rice distribution system, government through the Presidential Instruction controls the standard price of dry harvested paddy (known as GKP in Indonesian language) in farmer stage (IDR 3,700/ $\mathrm{kg}$ ), threshed product in the RMU (IDR 3,750/kg), and dry unhusked paddy (known as GKG) in RMU (IDR $4,600 / \mathrm{kg}$ ), in line with BULOG guidelines. The last factor denotes the buyer characteristics, in form of farmermiddleman relationship and also relates to negotiation capacity of farmer. As the middleman offers money to effect purchase, the farmer, in turn, proceeds to sell after reaching a mutual agreement. These factors tend to determine the selling price, harvest period and procedure, as well as bargaining process. Furthermore, farmers obviously consider the highest price offer as trading commences. The middleman in Figure 4 includes the entire stakeholders with connection to the supplier (farmer) and customer-consumer, e.g trader, RMU, and collector. In addition, the tier on the gray rectangular plays an essential role in the rice supply chain and distribution, while the dotted line shows the scope and function of BULOG. Figure 4 also reveals the importance of a control mechanism in regulating the supply chain and distribution system in order to ensure continuous assessment. This system involves five major factors,
In addition, several issues occurred along the supply chain, termed: 1) Long distribution channel leading to quality decline, attributed to poor management and price increase; 2) In reality, BULOG regularly purchase paddy or milled rice from farmers under the market price and this tends to result to insufficient stock in government warehouse; 3 ) The role of traders with RMU ownership is dominant and also involves market price determination; and 4) Several dealers tend to blend good quality rice with low grades, in order to boost profits. According to Nainabasti and Hu (2009), middlemen and traders are predominantly located in Nepal, due to the low level of farmer's education, under-developed infrastructure, and inefficient flow of market information into rural communities. Furthermore, farmers commonly demonstrates inadequate negotiation, but are known with the highest risk value among other stakeholders, specifically during pre-harvest activities (Tanuputri et al., 2014; Guritno et al., 2018). This condition, however, contributes to low farmers' welfare in Indonesia.

Based on the above description, rice supply chain appears very complicated, with the need for further improvement, using collaborative strategy. Long distribution channel, also called cross supply chain, occurred across several regions, including Central Java. For instance, paddy rice from Sleman was delivered to Demak to initiate milling, followed by a transfer to Sragen, and then to Delanggu for packaging with "Delanggu rice" label. The end product is subsequently returned to Sleman and sold in local markets at higher prices. In this situation, government probably controls the distribution activity by implementing the relevant policy. In addition, BULOG responsibilities are further strengthen in a bid to absorb market supply with increasing purchase prices. The agency currently acquire paddy or milled rice from the farmer or trader at a reduced rate, compared to 


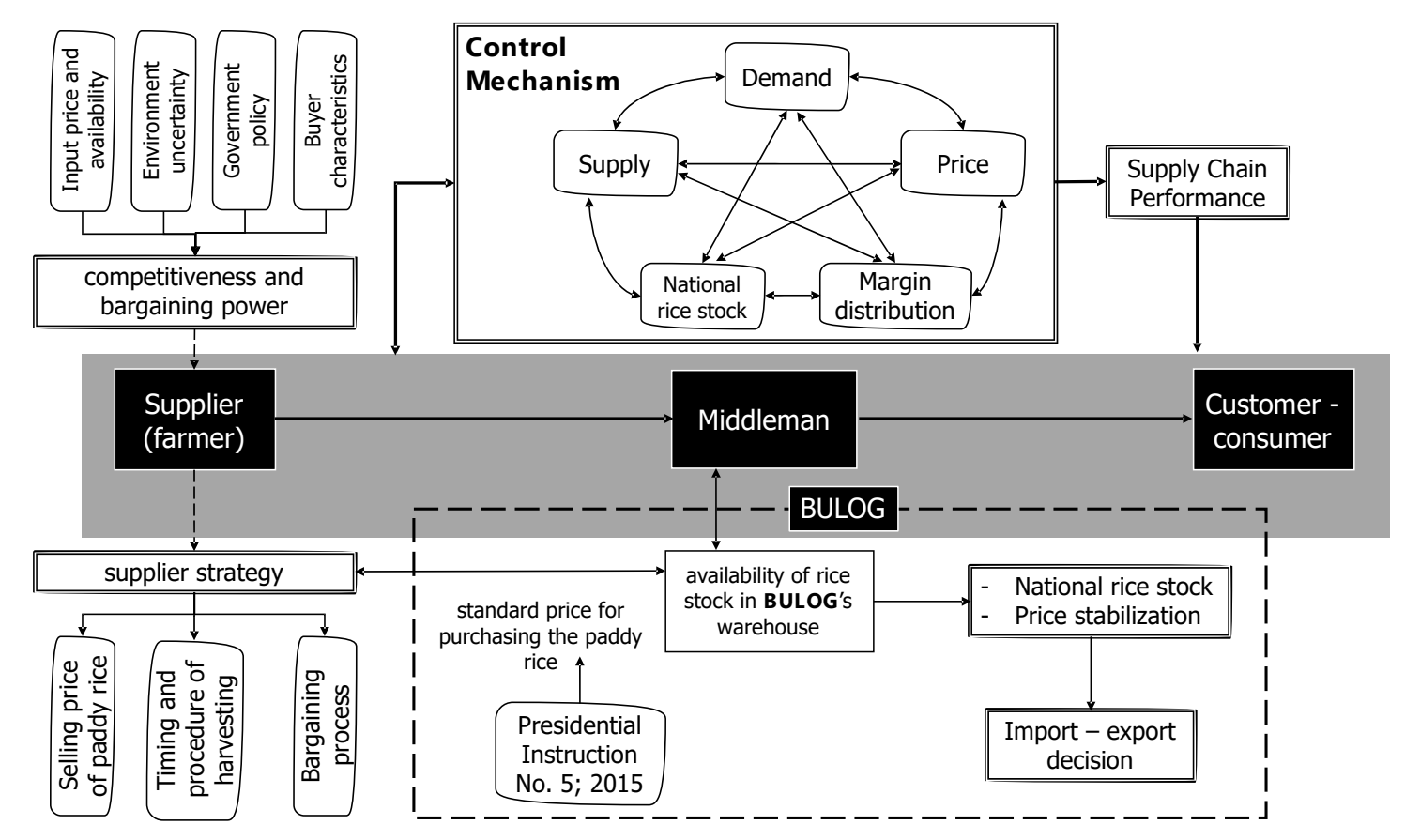

Figure 4. The conceptual framework for the implementation and management of rice supply chain

market price. Therefore, countless dealers sell to other stakeholders with extensive price offers. This condition leads to supply shortage in BULOG warehouse and instigates government towards importation, in an effort to secure more stock. Meanwhile, traders with ownership to rice milling unit, are typically dominant in determining market price, due to a large capacity to acquire the product from a wide range of communities. Also, at harvest peaks, these dealers are known to amass rice in very huge quantities, leading to shortage. This condition impact significantly on the increasing price of milled rice.

Therefore, collaborative strategies are needed to balance the demand and supply of rice in Indonesia, particularly in Central Java. The government is required to closely monitor the suspicious activities of trading mafias probably responsible for the price hike and also strengthen the purchasing power of BULOG on local rice, by increasing prices and reducing imports. In addition, guidance and assistance in terms of selling to BULOG, are encouraged. Furthermore, the role of farmers' association or cooperatives is extremely crucial in enhancing competitiveness and negotiating capabilities. This initiative provides is a means to minimize market access problems and linkage between cooperative and private sector operators, including traders, wholesales, and middlemen (Kumar \& Kushwaha, 2015). Most importantly, collaborative function in cooperatives are followed by the development of a prominent network to promote information sharing with respect to market demands, internal collective action, as well as build trust and transparency (Lee, 2002; ICA, 2016; Stringfellow et al., 1997; Vasa et al., 2014 in Sathapatyanon et al., 2018). Based on this study, the use of appropriate technology, conflict of interest in organizations, and resource management are key contributing factors to the inefficiency of farmers' association or cooperatives, as also reported by V. Balasubramanian in FAO (1998). Therefore, collaborative strategies are necessary, and are possibly achieved by promoting stakeholders participation at all levels in the effective control of rice distribution and quality, while providing extensive training opportunities on excellent customer practices and other related matters, in order to avoid unnecessary financial losses.

\section{CONCLUSION}

This study provides a comprehensive analysis of general rice supply chain in Central Java, comprised of six major stakeholders including the farmer, middleman (or harvester), rice miller, trader, BULOG and retailer. Each participant played a significant role, although more than a single function is readily available depending on the economies of scale and financial capability. The paper further revealed the farmers in Demak and Sukoharjo, Central Java, obtained the lowest revenue, compared to rice millers/traders and retailers. Also, in comparison, the farmers in Demak typically acquired wider land mass of paddy than in Sukoharjo, where higher productivity was 
reported. As bidding and bargaining process for paddy rice normally commences 14 days prior to harvest, adequate control and monitoring measures become very crucial. Moreover, the farmer generated revenue worth approximately IDR $300-600 / \mathrm{kg}$, while the trader and retailer acquired IDR 4,800/kg and IDR 300/kg, respectively. This condition appeared unfair, based on the higher risks prevalent from the farmer's perspective, although, the traders were known to generate these highest rates, due to providing the most added value and were also more effective in negotiations. Under this research, long distribution system, dominancy of traders in market price determination, and poor handling by BULOG in price stability, were among significant factors contributing to the complexities in rice supply chain and distribution system. Therefore, collaborative strategies are required to enhance efficiency, as government is expected to closely monitor rice distribution and also strengthen the roles of BULOG in ensuring local consumption.

\section{ACKNOWLEDGEMENT}

The author is grateful for the provision of funding by the Ministry of Agriculture, Indonesia through the Indonesian Agency for Agricultural Research and Development (Badan Penelitian dan Pengembangan Pertanian) under the agreement letter no 148.8/ PL.040/H.1/04/2018.K on 02 April 2018, as this study was conducted in the Department of Agroindustrial Technology, Universitas Gadjah Mada, Indonesia. Also, the author is grateful to all enumerators for offering significant support during data collection in Central Java Province, as well as to the respondents.

\section{CONFLICT OF INTEREST}

The author states the article is an original research, and has not been previously published in another journal, and therefore, no conflict of interest exists.

\section{REFERENCE}

Adam, M., Marwa, T., Azwardi, A., Thamrin, K.M.H., \& Bashir, A. (2017). Analysis of Rice Distribution in South Sumatera, Indonesia. International Journal of Economics and Financial Issues, 7 (3), 166 - 171. https://www. econjournals.com/index.php/ijefi/article/view/4528

Antriyandarti, E. (2015). Competitiveness and Cost Efficiency of Rice Farming in Indonesia. Journal of Rural Problems, 51 (2)., 74 - 85. https://doi.org/10.7310/arfe.51.74
Chung, B., Arshad, F.M., Noh, K.M., \& Sidique, S.F. (2016). Cost analysis of rice milling: a case study of 7 rice mills in Malaysia. Journal of Agribusiness in Developing and Emerging Economies, 6(2), 173 - 190. https://doi. org/10.1108/JADEE-05-2014-0019

Correa, H.L. (1994). Linking Flexibility, Uncertainty and Variability in Manufacturing Systems: Managing Unplanned Changes in the Automotive Industry. Aldershot: Avebury.

FAO. (1998). Rice Post-Harvest. Retrieved from http://www. fao.org/3/X5427E/X5427E00.htm

Fukui, S., Hartono, S. \& Iwamoto, N. (2002). Risk and rice farming intensification in Rural Java. The Japanese Journal of Rural Economics, 4. https://doi.org/10.18480/ jjre.4.32

Guritno, A.D. (2016). Supply Chain Risk Management: An Approach to Reduce the Agricultural Product's Logistics Costs. KnE Life Sciences, 3, 6 - 11. https://doi. org/10.18502/kls.v3i3.397

Guritno, A.D.; Kristanti, N.E.; \& Tanuputri, M.R. (2018). Risk Mitigation on Supply Chain of Rice: Case Study at Demak and Sleman Regencies. agriTECH, 38 (3), 375 - 380. http://doi.org/10.22146/agritech.38529

Kumar, V., Fantazy, K.A., Kumar, U., \& Boyle, T.A. (2006). Implemetation and Management Framework for Supply Chain Flexibility. Journal of Enterprise Information Management, 19(3), 303-319. https://doi. org/10.1108/17410390610658487

Kumar, A., \& Kuswaha, G.S. (2015). Value stream mapping: a tool for Indian agri-food supply chain. IRC's International Journal of Multidisciplinary Research in Social and Management Sciences, 3(1), 45 - 54. https://papers. ssrn.com/sol3/papers.cfm?abstract_id $=2970327$

Lambert, D.M., Cooper, M.C., and Pagh, J.D. (1998). Supply Chain Management: Implementation Issues and Research Opportunities. The International Journal of Logistics Management, 9(2), 1-20. https://doi. org/10.1108/09574099810805807

Ministry of Agriculture. (2016). Outlook of Agriculture Commodity: Rice. Jakarta: Centre for Data and Agricultural Information System, Ministry of Agriculture.

Nainabasti, A. \& Bai, H. (2009). Rice Marketing System and Role of Middlemen in Nepal: A Case Study of Chitwan District. Journal of Rural Problems, 45 (1), 14 - 23. https://doi.org/10.7310/arfe.45.14

Rahman, S.M., \& Takeda, J. (2007). Measuring the cost of production based on size of farm operation: A study on rice farmers in Jessore Districts of Bangladesh. American Journal of Applied Science, 4(5), 274-283. https:// thescipub.com/pdf/10.3844/ajassp.2007.274.283 
Sathapatyanon, J., Kuwornu, J.K.M., Shivakoti, G.P., Soni, P., Anal, A.K., \& Datta, A. (2018). The role of farmer organizations and networks in the rice supply chain in Thailand. Journal of Agribusiness in Developing and Emerging Economies, 8(3), 554 - 578. https://doi. org/10.1108/JADEE-01-2017-0016

Statistics Indonesia. (2018). Executive Summary 2018: Harvested Area and Rice Production in Indonesia. Jakarta: Subdirectorate od Food Crops Statistics, Statistics Indonesia.
Statistics Indonesia. (2020). Harvested Area, Production and Productivity of Paddy by District 2018. Retrieved from https://jateng.bps.go.id/dynamictable/2016/12/19/44/ luas-panen-produksi-dan-produktivitas-padi-provinsijawa-tengah-menurut-kabupaten-kota-2018.html

Tanuputri, M.R., Guritno, A.D., \& Kristanti, N.E. (2014). Supply Chain Risk Management and Logistics Cost Structure Analysis of Corn (Zea mays L.) to Reduce the Negative Effects of Mycotoxins Growth. Bangkok: Proceeding of The 16th Food Innovation Asia Conference 2014. 